\title{
Macroeconomics After the Great Recession
}

\author{
Emine Boz ${ }^{1} \cdot$ Linda Tesar $^{2}$
}

It has been more than 9 years since the outbreak of the global financial crisis. Although recent growth forecasts have improved, the world economy remains in recovery mode. Unemployment rates are gradually returning to pre-crisis levels, central bankers are contemplating the unwinding of large asset positions and the lifting of interest rates, and policymakers are grappling with elevated levels of public debt along with conditions of tepid growth and sluggish private investment. The theme of the IMF's 17th Jacques Polak Annual Research Conference on Macroeconomics held in Washington D.C. on November 3-4, 2016 was "Macroeconomics after the Great Recession." The fall of 2015 marked Olivier Blanchard's retirement as IMF Economic Counsellor and Director of the Research Department, so the conference was an opportunity to honor his contributions to the IMF and to recognize his sweeping contributions to the field of macroeconomics.

Olivier joined the IMF on September 1, 2008, just days before the Lehman bankruptcy and the onset of the global financial panic. As Managing Director Lagarde noted in her opening remarks, "within weeks [Olivier] was able actually to forge a recommendation that included a massive cleaning up of the banking system ... and a stimulus package that was not exactly along the lines of what typically the IMF is associated with. ... [W] [Wen policymakers around the world scrambled to contain the impact of the crisis, they turned first and foremost to the IMF, and the IMF turned itself to its Research Department very ably led by Olivier. They all came to the right place." Managing Director Lagarde also credited Olivier for his willingness to tackle controversial topics and to challenge economic orthodoxy. During his tenure, Olivier organized three "rethinking macroeconomics

Emine Boz

\footnotetext{
Wasington, DC, USA

Ann Arbor, MI, USA
} 
conferences," with the goal of opening "the Fund as well as the wide academic and policymaking community to new ideas."

The coincidence of the Annual Research Conference and an event honoring Olivier made the organization of the conference both very easy and simultaneously quite difficult. It was easy because Olivier's work touches on virtually all of the major macroeconomic issues that currently challenge policymakers and stimulate academic research and easy also because so many of the world's leading macroeconomists owe an intellectual debt to Olivier and wished to be a part of this event. It was difficult because-while the conference tackled a broad range of issues over two days involving many papers and discussants-tough choices had to be made over which topics to cover and which papers to include. Indeed, the scope and quality of the conference is reflected in the fact that the conference volume extends to two full issues of the IMF Economic Review. Below we summarize the key contributions of the papers that appear in this first of the two conference issues.

The conference opened by examining changes that have occurred in factor markets. "Investment Hollowing Out" by Lewis Alexander (Nomura Securities International) and Janice Eberly (Northwestern University and NBER) use US firmlevel data to document shifts in investment from production sectors that can be relocated (such as manufacturing) toward spatially "grounded" industries (such as energy and telecommunications) from which capital cannot be relocated. The hollowing out of manufacturing is thus reflected in the hollowing out of investment more generally. The strong growth of high-tech firms is insufficient to provide a boost to the share of capital investment in the economy overall as those firms tend to invest in intangible, rather than physical, capital. These shifts in investment mirror similar changes in the allocation of labor across sectors, and in both cases, the shifts started well before the Great Recession.

"The Effects of Labor and Product Market Reforms: The Role of Macroeconomic Conditions and Policies" by Romain Duval (IMF) and Davide Furceri (IMF) improves our understanding of the conditions that support successful reforms. The paper adds to a large literature on this subject, including earlier work by Olivier with co-authors Francesco Giavazzi and Justin Wolfers. Duval and Furceri find that product market reforms are generally successful in raising productivity and output. In contrast, the macroeconomic impact of labor market reforms depends on business cycle conditions. Some policies, such as reductions in labor tax wedges and increases in public spending, have larger effects during periods of slack. Other reforms, such as changes in employment protection arrangements and unemployment benefits, have positive effects only in good times.

The next paper turns to the challenges facing monetary policy in the aftermath of the global financial crisis. "The Tradeoffs in Leaning Against the Wind" by Francois Gourio (Federal Reserve Bank of Chicago), Anil Kashyap (University of Chicago) and Jae W. Sim (The Board of Governors of the Federal Reserve System) examines whether monetary policy should "lean against the wind" and counteract excess credit growth, or should focus on the goals of lower inflation and output stability. They assess this trade-off using a New Keynesian dynamic stochastic general equilibrium model that links the risk of financial crises to excess credit. In their calibration, financial crises are rare events with large real costs. In the face of 
such financial risks, the optimal monetary policy is to sacrifice some inflation and output stability and lean against the wind to limit credit growth. The paper explores alternative scenarios to highlight the various factors that affect this trade-off.

"Government Guarantees, Transparency, and Bank Risk-taking" by Tito Cordella (World Bank), Giovanni Dell'Ariccia (IMF and CEPR) and Robert Marquez (University of California, Davis) reveals a complex relationship between prudential policy and the institutional framework governing bank resolution and bailouts. In their framework, levered banks take excessive risk as their actions are not fully priced at the margin by debt holders. The impact of government guarantees on bank risk taking depends critically on the portion of bank investors that can observe bank behavior and hence price debt at the margin. Greater guarantees increase risk taking when informed investors hold a sufficiently large fraction of liabilities. But, otherwise, they reduce risk taking by increasing the profits of the bank.

Over the last decade, fiscal policy responses have varied a great deal across countries, depending on the depth of the recession, the constraints imposed by being part of a currency union, and the risks due to escalating debt. Some countries attempted fiscal stimulus; others adopted austerity by cutting government expenditures or raising taxes. The next paper exploits this heterogeneity by asking, "Is it the 'How' or the 'When' that Matters in Fiscal Adjustments?" by Alberto Alesina (Harvard University), Gualtiero Azzalini (NYU Stern), Carlo Favero (University of Bocconi), Francesco Giavazzi (University of Bocconi), and Armando Miano (Harvard University). The paper studies the output effects of fiscal adjustments as a function of the composition and timing of the adjustment over the 1981-2014 period. The analysis reveals that both the "how" and the "when" matter, but the heterogeneity related to the composition is more robust across different specifications. The paper finds adjustments based in the form of permanent spending cuts to be consistently much less costly than those based upon permanent tax increases. The results also suggest that the impact on output is generally not explained by the stance of monetary policy.

The final paper in this issue focuses on capital flows. In "The External Wealth of Nations Revisited: International Financial Integration in the Aftermath of the Global Financial Crisis," Philip Lane (Central Bank of Ireland, Trinity College Dublin, and CEPR) and Gian Maria Milesi-Ferretti (IMF and CEPR) analyze changes in crossborder investment positions during and in the aftermath of the global financial crisis. They find that growth in cross-border investment positions relative to world GDP has come to a halt since the crisis, reflecting diminished cross-border activity by banks in advanced economies and the rising share of less financially integrated emerging economies in global GDP. FDI positions have expanded, unlike positions in portfolio and other investment. The increase in FDI is primarily explained by positions vis-à-vis financial centers, suggesting an important role for the increased complexity of the corporate structure of large multinationals.

This is the first issue of the IMF Economic Review under our editorship. We thank Pierre-Olivier Gourinchas for his superb leadership and we will strive to meet the high benchmark he set for the Review. The objective of the Review remains unchanged: to bring leading scholars together with policymakers to generate high- 
quality, policy-relevant research. The problems facing the global economy remain large, but so are the talents and commitment of the research community. We are excited about the future of the Review. 